NBER WORKING PAPER SERIES

ECONOMIC CONDITIONS AND U.S. NATIONAL SECURITY IN THE 1930S AND TODAY

\author{
Martin S. Feldstein \\ Working Paper 15290 \\ http://www.nber.org/papers/w15290
}

NATIONAL BUREAU OF ECONOMIC RESEARCH

1050 Massachusetts Avenue

Cambridge, MA 02138

August 2009

The views expressed herein are those of the author(s) and do not necessarily reflect the views of the National Bureau of Economic Research.

NBER working papers are circulated for discussion and comment purposes. They have not been peerreviewed or been subject to the review by the NBER Board of Directors that accompanies official NBER publications.

(C) 2009 by Martin S. Feldstein. All rights reserved. Short sections of text, not to exceed two paragraphs, may be quoted without explicit permission provided that full credit, including $\odot$ notice, is given to the source. 
Economic Conditions and U.S. National Security in the 1930s and Today

Martin S. Feldstein

NBER Working Paper No. 15290

August 2009

JEL No. E6,H0,H56

\begin{abstract}
$\underline{\text { ABSTRACT }}$
This paper comments on the experience of the U.S. economy in the 1930s, its lessons for managing the current economic downturn, and the relation of U.S. economic conditions to our future national security. Some of the conclusions are: (1) Although the current recession will be long and very damaging, it is not likely to deteriorate into conditions similar to the Depression of the 1930s. Policy makers now understand better than they did in the 1930s what needs to be done and what needs to be avoided. (2) The focus on domestic economic policies in the 1930s and the desire to remain militarily neutral delayed the major military buildup that eventually achieved the economic recovery. (3) A well-functioning system of bank lending is necessary for economic expansion. We have yet to achieve that in the current situation. (4) Raising taxes, even future taxes, can depress economic activity. The administration's budget proposes to raise tax rates on higher income individuals, on dividends and capital gains, on corporate profits and on all consumers through the cap and trade system of implicit $\mathrm{CO} 2$ taxes. (5) Inappropriate trade policies and domestic policies that affect the exchange rate can hurt our allies, leading to conflicts that spill over from economics to impair national security cooperation. Reducing long-term U.S. fiscal deficits would reduce the risk of inflation and thereby reduce the fear among foreign investors that their dollar investments will lose their purchasing power. (6) The possibilities for domestic terrorism and of cyber attacks creates risks that did not exist in the 1930s or even in more recent decades. The scale and funding of the FBI and the Department of Homeland Security is not consistent with these new risks.
\end{abstract}

\author{
Martin S. Feldstein \\ President Emeritus \\ NBER \\ 1050 Massachusetts Avenue \\ Cambridge, MA 02138-5398 \\ msfeldst@nber.org
}




\title{
Economic Conditions and U.S. National Security in the 1930s and Today
}

\author{
Martin Feldstein*
}

In his annual report to the Congress, the new Director of National Intelligence identified the global economic crisis as the primary current threat to U.S. national security. He focused on the risk that falling incomes and rising unemployment in emerging market economies could destabilize those countries politically, a reminder of how the global economic downturn in the 1930s contributed to the rise of the Nazis in Germany and the fascists in Italy.

His surprising focus on an economic issue also understandably raised interest in the more general subject of the relation between economic conditions and U.S. national security. The organizers of this Aspen Strategy Group meeting have asked me to comment on the experience of the U.S. economy in the 1930s, its lessons for managing the current economic downturn, and the relation of U.S. economic conditions to our future national security.

The current economic downturn is the most severe recession since the 1930s, already longer than any of the 11 previous postwar recessions and likely to involve a substantially greater loss of GDP. It is more damaging and more difficult to end because its basic cause was different from that of previous recessions. Those downturns occurred after the Federal Reserve raised the real short-term interest

\footnotetext{
* Professor of Economics, Harvard University. This paper was prepared as a background document for the August 2009 meeting of the Aspen Strategy Group.
} 
rate to deal with an inflation problem. When the Fed concluded that the higher interest rate had slowed the economy sufficiently to deal with inflation, it reversed its policy and lowered the rate of interest enough to end the downturn.

In contrast, the current downturn was caused by a general underpricing of risk in financial markets and in other asset markets, leading to an excessive rise in leverage. While the defaults on subprime mortgages gave the first warning that this was about to end, the need to reprice assets was much more general. Unwinding the high leverage and the mispriced risk has left us with a financial system that remains dysfunctional and that is therefore not providing the credit that the economy needs for economic growth.

But despite these unusual problems, the current downturn is, as of now, far less severe than the Depression of the 1930s. Even the most pessimistic forecasters are not expecting a repeat of that experience. The level of real GDP has declined about 5 percent since this recession began. In contrast, real GDP fell 10 percent in the first year of the recession that began in 1929 and eventually declined more than 30 percent before it began a long slow recovery. The unemployment rate is now approaching 10 percent but rose to 25 percent in the 1930s despite a large number of public employment programs. Current systems of unemployment insurance, Social Security, and Medicaid mean that there is far less personal hardship than there was in the 1930s.

The current situation also differs from the 1930s in several other specific ways that reduce the risk that today's economy will deteriorate into a major 
Depression. I will note just three of them. First, in the 1930s, banks were the primary source of credit while now the capital markets and various nonbank institutions play major roles in credit creation. Second, Federal government insurance of bank deposits means that a bank failure no longer destroys the wealth of the depositors and the fear of bank failures no longer leads to bank runs as it did in the 1930s. Third, the expansion of federal government spending since the 1930s provides a large stable component of aggregate national demand.

Against these favorable conditions is one important negative difference since the 1930s. Because financial wealth was much more concentrated in the 1930s than today, the collapse of the stock market had a direct effect on many fewer households than it does in today's economy, characterized by 401k plans and IRAs.

Nevertheless, unless our economic policies are very badly managed in the coming year, we will not slide into a downturn of the scale of the 1930s.

\section{U. S. Economic Experience in the 1930s}

One reason for optimism about current economic policies is that professional thinking about economic policy is very different today than it was in the 1930 s. Policy officials should therefore be able to avoid the mistakes that turned the recession that began in August 1929 into the great Depression.

Thanks to the work of John Maynard Keynes and of Milton Friedman, we now have a better understanding of how governments can (at least in principle) reduce the severity of major economic downturns. Keynesian economics taught us that government spending can raise GDP and reduce unemployment. Friedman's work 
taught us that temporary tax cuts and transfers that temporarily raise personal incomes are relatively ineffective (unless they change the incentive to spend) while permanent tax increases (even if their starting date is delayed) will depress current spending.

Friedman's analysis of monetary policy in the depression also taught us that maintaining or expanding the "money supply" (i.e., the volume of currency and bank deposits) is important for sustaining and growing aggregate demand. The contraction of the money supply in the 1930s was particularly damaging because the supply of bank money was also the basis for the supply of credit to businesses and households.

Because these lessons were not known in the 1930s, the depression lasted longer and was deeper that it could otherwise have been. The Federal Reserve actually reduced the money supply by 30 percent between 1928 and 1933 . The Roosevelt administration flailed around with a variety of counterproductive microeconomic policies (the NRA, WPA, CCC, Wagner Act, etc). The scope for expansionary fiscal policy was very limited. Since federal government spending was only 3.4 percent of GDP in 1930 , even the 40 percent rise in nominal federal government spending that resulted from the various Roosevelt spending programs was only equivalent to two percent of GDP.

There was also little room for a permanent tax cut since federal tax revenue was only 4 percent of GDP. Quite remarkably, the government actually doubled tax rates on high-income individuals between 1929 and 1932 and then raised them 
further in 1936! The only successful macroeconomic policy was the result of temporarily leaving the gold standard in 1933, and then returning at a higher price of gold the following year, an action that automatically caused an increase in the money supply. The unemployment rate remained at more than 17 percent as late as 1939 and declined substantially only when the government began a serious military buildup after the U.S. formally entered the war on the Axis powers in 1941.

\section{Current Macroeconomic Policies}

Friedman's lessons about the importance of money and credit helped to shape Fed policies in the current downturn. In addition, the Federal Reserve and the Treasury have acted forcefully in an attempt to extend credit in the economy. In addition to policies to help the banks, they supported credit through money market mutual funds, commercial paper, Fannie and Freddy mortgages, and even various consumer loans. But the banks have restricted their lending because the rising rate of defaults on mortgages and other loans creates uncertainty about the value of their existing assets and therefore of their capital. The Treasury's TARP program and the more recent Public Private Investment Partnerships (PPIP) are attempts to resolve the banks' problems but, for a variety of reasons, they have not been successful in removing the toxic assets from the banks' balance sheets. It is not clear whether the administration and Congress will agree on the steps needed to fix the PPIP program in a way that will lead to a recovery of bank lending.

The Obama administration recognized the need for a Keynesian fiscal stimulus but underestimated the amount of stimulus and the speed of action that 
was needed to offset the combined effect of reduced consumer outlays and the fall in residential investment. Because of the specific design of the stimulus package it delivered relatively little increase in GDP per dollar of increased national debt.

Only about 25 percent of the increased national debt will be an increase in federal government purchases of goods and services in 2009 through 2011. The remaining 75 percent will reductions in taxes and increases in transfers to households or increases in transfers to state and local governments. Consumers have responded to transfers and temporary cuts in taxes by saving most of the resulting increase in income. For example, the most recent rise in personal income of $\$ 180$ billion between April and May 2009 led to a rise in consumer spending of only $\$ 25$ billion with the rest going to pay debts or accumulate financial assets. A substantial portion of the transfers to states will be saved or used to finance spending that would otherwise have been financed with available revenues.

In short, although the basic conceptual lessons that followed from the experience of the 1930s caused a fundamental qualitative shift in monetary and fiscal policies, the magnitude of the government's actions have not been adequate to the problems that we now face. The fiscal stimulus will cause a temporary reduction in the rate of economic decline in the second and third quarters of 2009, but is unlikely to do enough to start a sustained expansion this year. Without knowing what new policies will be adopted, it is impossible to know when a sustained recovery will actually begin.

\section{International Issues: Trade and the Dollar}


International trade and exchange rates are controversial issues in the best of times but can become a source of serious conflict when the economy is weak. Trade conflicts can at a minimum make it difficult to achieve cooperation on other international security policies. Although we are now likely to avoid the blatant protectionist policies of the 1930s and the resulting reciprocal tariff wars, some of the policies that are now being considered could have the same effect of creating trade conflicts. It is therefore worth understanding what happened in the $1930 \mathrm{~s}$ and where similar trade conflict risks lie in current policies.

The value of the dollar and its role as a reserve currency has already become a source of friction between the United States and China. The administration has yet to enunciate a policy in response to its critics and is pursuing domestic policies that could exacerbate this issue.

This section looks first at the trade issues and then at the current exchange rate problem.

The centerpiece of America's international trade policy in the 1930s was the Smoot-Hawley tariff, enacted in 1930 to reduce imports by causing American firms and households to shift their purchases to American made goods. Because the tariff rates were related to physical volumes of imports (e.g., \$1.12 per ton of pig iron), the sharp fall in the U.S. price level (down 29 percent from 1929 to 1932) caused the implied effective tariff rate to rise rapidly. While the Smoot-Hawley bill initially only raised the already high average tariff rate from 38 percent to 41 percent at the 
time of passage, the decline in the price level eventually caused the average tariff rate to rise to 60 percent.

The passage of Smoot-Hawley hurt the exports of foreign countries. That led to retaliatory increases in foreign tariffs that reduced US exports by more than U.S. producers gained from the "buy American" effect of the Smoot-Hawley tariff. Fortunately, since international trade was then only a small part of the U.S. economy, the depressing effect on economic activity was also relatively small. The net exports of the United States fell by less than one percent of GDP. But the passage of the Smoot-Hawley tariff not only depressed U.S. economic activity but also reinforced a sense of economic nationalism among our trading partners and led them to conclude that the U.S. did not care about their economic hardship.

Although the post-war tradition of GATT rules and WTO conventions will probably prevent a repeat of the 1930s style unapologetically protectionist tariffs, there is a danger that some of the recent U.S. policies and proposed future policies will lead to harmful reductions in trade and to increases in trade conflict. The "Buy American" provision of the recent fiscal stimulus act requires that all products paid for by the stimulus funds be made in America unless doing so would violate international agreements. In practice, state and local governments and others using stimulus funds have focused on the injunction to buy American, inducing retaliation and threats of retaliation by foreign governments and firms. This is likely to become a much bigger problem as the volume of purchases funded by the stimulus package grows. 
The Administration's cap and trade policy for reducing CO2 emissions may, if enacted, lead to a more serious problem of explicit tariff increases and retaliation by foreign governments. Any cap and trade policy would raise the prices of Americanmade CO2-intensive consumer goods. Those higher prices would put American products at a competitive disadvantage relative to similar goods produced in other countries. If the cap and trade policy becomes law, American firms will ask for "border adjustment" tariff increases and for export subsidies to achieve what they will call a "more level playing field."

Surprisingly, WTO officials have already said that such tariffs and subsidies could be WTO compatible, perhaps by analogy with VAT border adjustments. But the product-by-product price increases caused by cap and trade would be vastly more difficult to estimate than the impact of value added taxes, especially in a system like the Waxman-Markey bill with permit giveaways and a wide range of allowable purchased "offsets". The legislation would therefore create ample opportunities for all firms to claim protection and export assistance and for foreign governments to argue that all such adjustments were inappropriately large. This could cause significant trade frictions with our trading partners, especially with China, India, and other emerging market countries that will not impose similar cap and trade policies or other comparable carbon taxes.

Such trade frictions would make it more difficult to achieve cooperation on other aspects of economic policy, especially security related trade policies like the imposition of tariffs and embargoes on a country like Iran. 
A declining dollar could be a further source of economic conflict and political disagreement between the United States and other countries. The real trade weighted value of the dollar fell by 25 percent between 2002 and 2008, primarily because of the enormous U.S. trade deficit. Since then it rose by about 13 percent, leaving a net decline since 2002 of 15 percent. The rise of the dollar since early 2008 reflected the desire of American and foreign investors to hold dollars because of the extreme uncertainty caused by the financial crisis.

As economic conditions stabilize, portfolio investors in the United States and elsewhere - including governments and non-government investors - are likely to want to shift more of their foreign exchange from dollars to other currencies. Recent comments by senior officials in Russia, China, and India - all major holders of dollars - indicate that such portfolio shifts may occur in the next few years.

A fall in the value of the dollar relative to other currencies is a natural and necessary response to the massive trade imbalances. A lower dollar will make U.S. products more attractive in foreign markets and U.S. goods and services relatively more attractive in the United States. But if this occurs at a time of economic weakness abroad, the rise in imports of U.S. products and the fall in exports to the United States could lead foreign governments to adopt policies to restrict U.S. imports and to promote foreign exports. That in turn could lead to increased conflicts over trade policy.

Foreign governments with large dollar investments are understandably nervous about the value of the dollar. Although their criticisms are about the role of 
the dollar as a reserve currency, the dollar investments of the Chinese and other major holders of dollars are far greater than traditional reserve balances. These are major forms of national investment, whether held in sovereign wealth funds or other accounts.

The legitimate concern of the Chinese, for example, is not about the future exchange rate between the dollar and the Chinese yuan but about the future purchasing power of the dollar, i.e., about future inflation in the United States. They worry that the massive U.S. budget deficits and the explosion of reserves at the commercial banks could lead to future inflation that makes their dollars buy fewer U.S. goods.

If they act on these worries, they will shift more of their foreign exchange investments from dollars to other currencies. That would lower the value of the dollar and increase U.S. inflation. It would also cause long-term U.S. interest rates to rise, reducing the value of the bonds and hurting the U.S. economic recovery. It is not clear what retaliatory policies the United States might contemplate under those circumstances. But foreign investors may fear a modern-day equivalent of closing the gold window to deny foreign investors the free access to sell their dollar balances.

A policy that would reassure foreign investors of the future purchasing value of their dollar assets would involve reducing future fiscal deficits and making clear that the Federal Reserve will prevent domestic inflation even if that requires raising 
interest rates during the early stage of the recovery when unemployment rates are still quite high.

\section{U. S. Economic Conditions and National Security Issues in the 1930s}

The Hoover and Roosevelt administrations were so focused on domestic economic weakness until the late 1930s that they essentially ignored the deteriorating security conditions in Europe and in the Far East that would eventually drag the United States into war with Germany, Italy, and Japan. In retrospect, the great irony of the economic policies of the Roosevelt administration was that the isolationist focus on domestic issues postponed the very policies of military assistance and U.S. mobilization that eventually brought the United States to a full recovery.

Economic considerations conditioned the way that the U.S. reacted to specific foreign events. The United States did nothing substantive to respond to the aggressive actions of Germany in central and eastern Europe, of Italy in Ethiopia, and of Japan in China. While the U.S. protested the Japanese invasion of Manchuria, it muted its protests because of the importance of U.S.-Japan trade. The U.S. refused to admit Jewish refugees from Hitler's Germany because of (or rationalized by) a concern about the impact of immigrants on the employment of Americans at a time of very high unemployment. 
The isolationist sentiment in the United States and the decision to focus on the U.S. domestic economy led to the Neutrality Acts of 1935, 1936, and 1937 that restricted the sale of munitions to any of the belligerents. This effectively helped Germany and Japan because they had the domestic manufacturing capacity that was lacking in Britain, France, and China.

Budget deficits were a political constraint on military expenditures, reinforcing the political desire to belittle the risks to the United States of the events on the other sides of the two oceans. The federal budget shifted from a small surplus in 1930 ( $\$ 800$ million or 0.8 percent of GDP) to a deficit of $\$ 2.8$ billion or 4 percent of GDP just two years later. The primary reason for the deficit was the drop in tax revenue caused by the economic downturn. Nominal GDP fell by one-third between 1930 and 1932, causing federal tax revenue to decline from $\$ 4.1$ billion in 1930 (4.2 percent of GDP) to less than half that amount in 1932 ( $\$ 1.9$ billion or 2.8 percent of the reduced GDP.) This revenue decline occurred despite - or perhaps partly because of - a doubling of the income tax rates: the top tax rate (on incomes over \$1 million) rose from 25 percent in 1929 to 63 percent in 1932, the rate at $\$ 100,000$ rose from 25 percent to 56 percent, and even at an income of $\$ 10,000$ the marginal tax rate rose from 6 percent to 10 percent.

Despite the foreboding events in Europe and Asia, U.S. military spending began to rise only after 1936 and the increase was slow until war was declared in 1941. Spending on the Army and Navy (there was no airforce until after World War II) actually fell from $\$ 831$ million in 1931 (1.1 percent of GDP) to $\$ 705$ million in 
1934, also about 1.1 percent of GDP. Even as late as 1939, the combined Army and Navy outlays totaled just $\$ 1.4$ billion or 1.5 percent of GDP. But mobilization was underway in 1941, raising Army-Navy spending to $\$ 6.3$ billion (or 5.0 percent of GDP), four times the 1939 level. And by 1943 the Army-Navy spending had increased another ten-fold to $\$ 63.3$ billion or 32 percent of GDP.

The rise in military spending created the demand that pulled the economy out of the Depression. The Keynesian "multiplier" process meant that the total rise in GDP was more than enough to finance the increased Army and Navy budgets. By 1943 , the nonmilitary GDP had increased to $\$ 136$ billion, nearly 50 percent higher than in 1939. Even after adjusting for the price level increase, the real nonmilitary spending had increased by 14 percent.

\section{U.S. Economics and National Security Today}

The current national security situation of the United States is, of course, fundamentally different from the one that we faced 75 years ago. Yet there is a risk that we will again underestimate the dangers abroad and therefore will devote too little of our GDP to military spending and other forms of national security. And as in the 1930s, national security spending today could actually stimulate overall economic activity.

With the collapse of the Soviet Union, the U. S. nuclear umbrella no longer induces the kind of cooperation and support for U.S. policies among our traditional allies that it did in the earlier postwar decades. We are now part of a multipolar 
world in which the European Union, Japan, China, and Russia are independent actors pursuing their own national interests.

The Chinese are rapidly becoming a global economic power and potentially a global military power. Although China's per capita income is still low by western standards, China's population of 1.3 billion people is more than four times that of the United States. If China's annual rate of real aggregate GDP growth continues to exceed that of the U.S. by just five percentage points (less than the gap in recent years), China's total real GDP (now nearly $\$ 8$ trillion at purchasing power parity prices) will exceed that of the US by 2025. While China's per capita income will still be relatively low, its large total GDP will allow it to support military and foreign policy activities comparable to that of the U.S. and Europe. By devoting a larger share of its national income to these activities, China would be able to do so even earlier than 2025 .

The financial crisis has amplified the voices of those who criticize capitalism in general and globalization (free trade and capital movements) in particular. The very visible success of the Chinese economy and the destructive effects of the IMF policies in Asia and Latin America in the late 1990s have called into question the "Washington consensus" guidelines for emerging market economies. There is a further danger, as the DNI's testimony earlier this year indicated, that the declining levels of income and employment in emerging market economies could destabilize the political regimes in those countries. Political actors like Chavez and Ahmadinejad are using their oil resource income to support governments and 
nongovernment groups working against U.S. interests. American spending on foreign assistance, on helping our natural allies, and on supporting programs that strengthen market economies could help to counter those threats.

Another source of risk to the United States is our position as a major international debtor, dependent on other countries to finance our large annual current account deficit and continually roll over our vast outstanding international debt. Foreign investment in the United States (including foreign ownership of U.S. businesses as well as portfolio investments in U.S. equities and bonds) is now more than $\$ 20$ trillion and now exceeds U.S. investments in the rest of the world by more than $\$ 3$ trillion. The additional 2009 current account deficit (the sum of the trade deficit and the net investment payments owed to foreign investors) that needs to be financed by foreign governments and foreign private investors is now running at about $\$ 400$ billion and is likely to rise in response to the recent increase in the price of oil.

Although we will inevitably attract foreign funds to finance the additional borrowing as long as we have a current account deficit, the risk is that foreign investors will be willing to provide those funds only at higher interest rates. A rise in interest rates caused by reduced foreign demand for U.S. securities would depress U.S. economic activity in the short run and economic growth over the longer term. One way to reduce this dependence is to cut our long-term fiscal deficits by limiting the projected growth of government spending. 
A further source of U.S. dependence on other countries is the increase in the relative volume of oil imports. The share of imports in total U.S. oil consumption has gone from about 15 percent in 1955 and 40 percent in 1975 to 65 percent today. The suppliers of that oil are not reliable allies. Since it is clear that we will not significantly reduce our dependence on oil imports any time soon, we must have the naval and other military capabilities to be able to protect our access to that oil in the middle east and the shipping of that oil in international waters.

The military threats facing the United States have also become more complex and more worrisome because of changes in technology and in the nature of our adversaries. In the 1930s we felt well protected by the distance of the United States from potential adversaries in Europe and Asia. The Soviet development of intercontinental ballistic missiles changed that after World War II. Today we face not only nuclear weapons but also biological and chemical weapons of mass destruction. We are only beginning to understand the potential destruction that could be caused by cyber attacks.

We now face three different kinds of adversaries. There are the traditional major powers (Russia and China) that could attack the United States with conventional or nuclear weapons. An increasing number of rogue states and regional powers (including North Korea, Iran, and potentially Pakistan) are developing similar capabilities. Nonstate terrorist actors like Al Qaeda could acquire and deliver a nuclear weapon or other weapon of mass destruction. All three types of adversaries have or could develop the ability to use cyber attacks. 
Despite the massive increase in threats to the United States, we have reduced our commitment to defense spending. The share of GDP devoted to defense declined from 9.1 percent in 1960 to 4.9 percent in 1980. After a temporary rise under President Reagan (to 6.2 percent of GDP), defense spending fell to 4.9 percent of GDP in 2008 (including the spending on the wars in Iraq and Afghanistan.)

The recent budget submitted to Congress by the administration significantly reduces the GDP share devoted to defense over the next decade. Defense outlays are projected by the Administration to decline from 4.9 percent of GDP to 3.8 percent in 2019. In real terms, defense spending would rise less than one percent a year.

The failure to support a more robust defense is a matter of political choice rather than economic necessity. The growth of the entitlement programs (i.e., of the so-called "mandatory programs") and the unwillingness to raise the tax share of GDP have together forced a large reduction in the share of GDP available for defense. More specifically, total federal tax revenue was 19.7 percent of GDP in 1969 and is projected in the Obama budget to be nearly the same (20.3 percent) in 2019. During the same half century, the mandatory "entitlement" programs rose from 5.6 percent of GDP in 1969 to 11.2 percent of GDP this year and are projected to increase to 13.2 percent in 2019. That 7.6 percent of GDP rise in entitlements between 1969 and 
2019 will come primarily from reduced defense spending, down by 5.3 percent of GDP.*

The share of GDP spent on defense could be increased permanently without cutting entitlements or raising marginal tax rates by reducing some of the special "tax expenditure" features of the federal income tax. For example, eliminating the current exclusion of employer payments for health insurance would raise more than $\$ 100$ billion a year in additional revenue, an amount equal to about 0.8 percent of current GDP and more than 20 percent of defense spending.

The decision to include virtually no defense spending in the stimulus package (only $\$ 13$ billion of the $\$ 787$ billion stimulus bill) reflected the political resistance to increasing defense outlays. I suggested in a Wall Street Journal article ("Defense Spending Would Be Great Stimulus," Wall Street Journal December 24, 2008) that a temporary surge in defense outlays would be an effective way to stimulate GDP in the current situation. That article led to discussions with each of the four service chiefs who confirmed that, as a result of several years of conflict in Iraq and Afghanistan, they had equipment that needed to be repaired and supplies and equipment that needed to be replaced. Such spending would not raise the defense

* The remaining 2.3 percent of GDP increase in entitlements and the 1.7 percent of GDP rise in interest on the national debt are balanced by for the increase in the fiscal deficit (up from a surplus of 0.3 percent of GDP in 1969 to the administration's projected deficit of 4.4 percent of GDP in 2019.) 
budget baseline but would simply bring forward in time the spending that would eventually have to be done.

The military leaders with whom I spoke also indicated that they could do substantial infrastructure spending on their bases in the United States. Such outlays could begin immediately because they would not need the kinds of local approvals that are required for civilian construction projects.

The defense services could also increase recruiting, training the new recruits with civilian skills and returning them to the private economy at the end of two or three years. Although these temporary recruits would not have performed useful military work during that time, they would have had valuable education and would be available as future members of the armed forces reserves.

I was surprised to learn that the services had been told by transition team members and later by the new White House officials that, because the recession had reduced national income, they would have to cut back their military spending. This of course has the economic logic exactly backward. Because of the economic weakness, a temporary rise in military spending would not require cutting back on other forms of public and private spending. It made no economic sense to tell the services that they had to cut back while the government was searching for other ways to spend money as part of the stimulus package.

The recent decision to establish a new Cybercommand is a clear recognition of the risks of cyber attacks as well as of cyber based military and industrial espionage. Foreign governments and government related actors use cyber 
espionage to steal military and industrial secrets. These governments or their agents have also planted "bugs" in the systems of U.S. public utilities (including the electric grid, city water systems, and transportation control systems) that could allow them to cause those systems to malfunction or to completely stop functioning. Unfortunately, the ability of the Cybercommand and of the Department of Homeland Security to develop a robust defense against cyber espionage and cyber attacks is being restrained by concerns about the invasion of privacy. Now that the cyber risks are explicitly recognized, there are likely to be substantial national security and economic benefits from working with other nations to develop ways of preventing a dangerous escalation of cyber attacks.

Finally there is the problem of preventing organized terrorist activity in the United States, including future events like the 9-11 attacks. Substantial progress has been made in recent years to shift the mandate of the FBI from its traditional crime fighting role to a broader focus that emphasizes counter-terrorism. Changing the culture of an organization like the FBI is of course very difficult and some of its rules, procedures, and organizational structures are still more suited to crime fighting than to counterterrorism. Although some of the legal restrictions on FBI activities have been modified to allow it to be more effective in counterterrorism, the FBI is still restricted in ways that do not hinder the British MI5. Moreover, the FBI budget process and the magnitude of its resources have not expanded in line with its increased responsibilities. 


\section{$\underline{\text { A Concluding Comment }}$}

While it is difficult to summarize the complex economic and national security lessons of the 1930s, several points seem clear.

(1) Although the current recession will be long and very damaging, it is not likely to deteriorate into conditions similar to the Depression of the 1930s. Policy makers now understand better than they did in the 1930s what needs to be done and what needs to be avoided.

(2) The focus on domestic economic policies in the 1930s and the desire to remain militarily neutral delayed the major military buildup that eventually achieved the economic recovery. The administration's current budget point to a one-fifth reduction in the share of GDP devoted to defense over the next decade. In light of the increased range of adversaries and threats that the nation now faces, there are likely to be substantial national security benefits to increasing the share of GDP devoted to defense and other aspects of international security.

(3) A well-functioning system of bank lending is necessary for economic expansion. We have yet to achieve that in the current situation.

(4) Raising taxes, even future taxes, can depress economic activity. The administration's budget proposes to raise tax rates on higher income individuals, on dividends and capital gains, on corporate profits and on all consumers through the cap and trade system of implicit CO2 taxes. 
(5) Inappropriate trade policies and domestic policies that affect the exchange rate can hurt our allies, leading to conflicts that spill over from economics to impair national security cooperation. Reducing long-term U.S. fiscal deficits would reduce the likelihood of future inflation and thereby reduce the fear among foreign investors that their dollar investments will lose their purchasing power.

(6) The possibilities for domestic terrorism and of cyber attacks creates risks that did not exist in the 1930s or even in more recent decades. The scale and funding of the FBI and the Department of Homeland Security is not consistent with these new risks.

Cambidge, MA

July 2009 